University of Nebraska - Lincoln

DigitalCommons@University of Nebraska - Lincoln

9-1969

\title{
Morphology and Development of the Flowers of Boottia cordata, Ottelia alismoides, and Their Synthetic Hybrid (Hydrocharitaceae)
}

Robert B. Kaul

University of Nebraska-Lincoln

Follow this and additional works at: https://digitalcommons.unl.edu/bioscifacpub

Part of the Biology Commons, and the Botany Commons

Kaul, Robert B., "Morphology and Development of the Flowers of Boottia cordata, Ottelia alismoides, and Their Synthetic Hybrid (Hydrocharitaceae)" (1969). Faculty Publications in the Biological Sciences. 856. https://digitalcommons.unl.edu/bioscifacpub/856

This Article is brought to you for free and open access by the Papers in the Biological Sciences at DigitalCommons@University of Nebraska - Lincoln. It has been accepted for inclusion in Faculty Publications in the Biological Sciences by an authorized administrator of DigitalCommons@University of Nebraska - Lincoln. 


\title{
Morphology and Development of the Flowers of Boottia cordata, Ottelia alismoides, and Their Synthetic Hybrid (Hydrocharitaceae)
}

Robert B. Kaul

Department of Botany, University of Nebraska, Lincoln, Nebraska, USA

\begin{abstract}
The inferior ovary of Boottia cordata, Ottelia alismoides, and their hybrid is appendicular in nature, the carpels are congenitally only slightly connate, and they are unsealed. All floral organs except the sepals originate from common primordia in the female and bisexual flowers. A flat residual floral apex is present. There is a vestigial superior ovary of three ontogeneticallv fused carpels in the male flower of Boottia cordata. The hybrid is intermediate in many characteristics and has partially fertile stamens and staminodia. The sequence of development in all flowers is acropetal. These plants appear to be related to the Butomaceae and they show evolutionary tendencies parallel to those in the Nymphaeaceae.
\end{abstract}

The flowers of the Hydrocharitaceae exhibit a great range of morphological diversity with those of Ottelia alismoides (L.) Pers. and Boottia cordata Wall. the least specialized. The more primitive flowers of the family are characterized by actinomorphy, trimerous perianths differentiated into calyx and corolla, and inferior ovaries of 6-24 carpels with laminar placentation. They are entomophilous. The male flowers of the less-specialized genera have numerous stamens and staminodia. Flowers of each sex often have rudiments of the opposite sex, and dioecism is characteristic of most genera. Advanced members of the family show reduction in size and numbers of parts often associated with specialized hydrophilous pollination.

Vascular anatomy and floral morphology of most genera were described earlier (Kaul, 1968a), and it was shown that reduction has occurred in the perianth, androecium, gynoecium, and vascular system. This investigation adds ontogenetic and phylogenetic data which help to answer some questions raised earlier. An attempt has been made to elicit expression of vestigial structures by hybridizing these two taxa-one with perfect flowers, the other dioecious. Boottia cordata sometimes has been considered to be a species of Ottelia and hybridization supports that conclusion. To provide consistency with my earlier discussion, I will retain Boottia cordata.

\section{Methods and Materials}

Ottelia alismoides was grown from seeds I collected in Ceylon; Boottia cordata was raised from seeds collected in central Burma by A. L. Bogle. Both grow well in the greenhouse pools at the University of Nebraska in ordinary potting soil and warm water. Both bloom continuously without supplemental lighting. The hybrid was made by transferring Ottelia pollen with a paintbrush to the female flowers of Boottia. Neither plant sets seed in our greenhouse without artificial pollination, presumably because appropriate pollinating insects are absent. Ottelia has been reported (ErnstSchwarzenbach, 1956) to be occasionally cleistogamous. Heavy seed set is obtained with artificial pollination. The difficulties of emasculating the bisexual flowers of Ottelia have so far prevented reciprocal crosses. The hybrids are self-fertile and fertile in backcrosses to Boottia.

Developing flowers of the parent plants were obtained by dissection. Some were fixed in FAA for gross study while others were embedded in paraffin, sectioned at $10 \mu$, and stained with safranin and fast green. Some fixed specimens were cleared in $1 \% \mathrm{NaOH}$ at $56^{\circ} \mathrm{C}$, rinsed, gradually dehydrated in ethanol, stained with basic fuchsin in 95\% ethanol, and mounted in xylene. Basic fuchsin proved to be an excellent stain for the rather poorly differentiated vascular tissues.

\section{Results}

\section{Male flower of Boottia cordata}

Boottia cordata is a dioecious, rooted aquatic with floating leaf blades, native to the Irrawaddy drainage of Burma. The male plants bear inflorescences of numerous flowers subtended by large, thick, warty spathes (Figure 2). Each inflorescence produces two or more flowers a day for several weeks and each flower lasts for 1 day. The inflorescence is highly modified as a condensed branching system. Each flower has a long pedicel which elevates it well above the water.

The perianth consists of three leathery green sepals alternating with three large white petals with yellow

Received for publication January 15, 1969.

This work was supported by research grant GB 7237 from the National Science Foundation. 


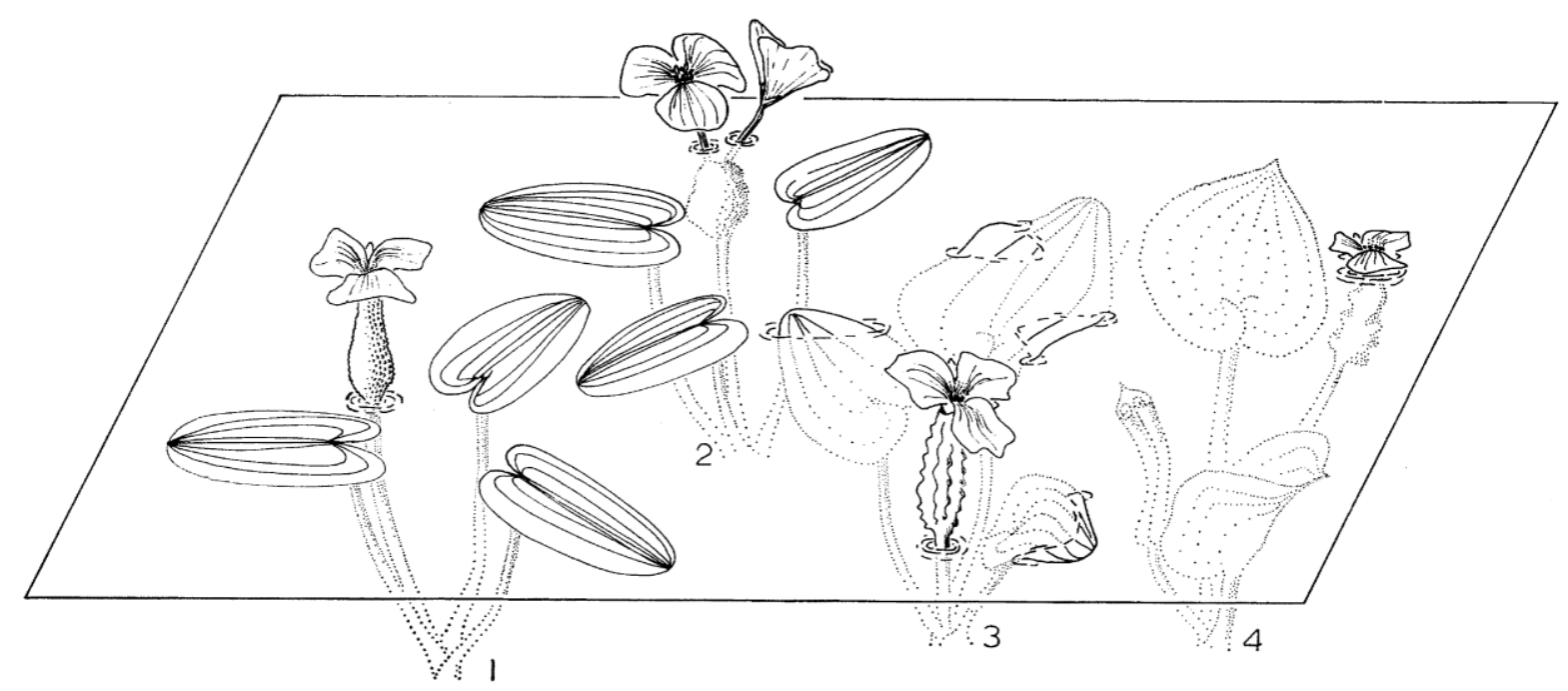

Figures 1-4. Habits of the plants. Only three of the many leaves of each plant are shown. | Figure 1. Female Boottia cordata. | Figure 2. Male Boottia cordata. | Figure 3. The hybrid. | Figure 4. Ottelia alismoides, completely submerged except for part of the flower. - All ca. X 0.12 .

bases. There are 12 fertile stamens occurring in radial pairs opposite the six perianth members. At maturity the inner six stamens are almost twice as long as their outer counterparts (Figure 14). The outer stamens have broader filaments. The filaments are distally hairy and the connectives are relatively broad (Figures 10 and 14). On the same radius as a sepal and acropetal to the stamens is a greatly elongated bifid staminodium (Figures 8 and 14). The lower portions of the arms and the filaments of these staminodia are abundantly hairy.

Above the staminodia is a six-lobed fleshy yellow body, the vestigial gynoecium, which is basally adnate to the staminodia at maturity (Figures 8 and 14). Weak vascular bundles enter this body from the receptacular plexus (Figure 8), and a single bundle enters each of the bifid staminodia and branches into its arms, where further branching occurs (Figure 8).

Large quantities of pollen are shed as the flower opens and the inner faces of the petals and the hairy parts of the staminodia become covered with pollen.

Sepal primordia appear in consecutive order shortly after the floral primordium itself is differentiated in the inflorescence. The first sepal is initially the largest and it remains so. Petal primordia arise simultaneously at the same time as the first stamen primordium. Extensive growth of the petals is delayed until near anthesis.

The fertile stamens arise acropetally in four alternating whorls of three members each, the first whorl antisepalous and the last antipetalous (Figures 11-13). Following appearance of the last whorl of fertile stamens three crescent-shaped primordia, the vestigial carpels, appear opposite the sepals (Figure 13). They become ontogenetically fused. It is only after they are well developed that the bifid staminodia appear opposite the sepals. The staminodia grow rapidly near anthesis and at anthesis they are up to one-half as long as the petals.

\section{Female flower of Boottia cordata}

A single sessile flower is produced in each inflorescence and it is enclosed by a spathe of thick, fused, warty bracts. The inflorescence is held above the water (Figure 1). The flower, the showiest in the family, may be $5 \mathrm{~cm}$ broad and $7 \mathrm{~cm}$ long and has three oblong leathery green sepals and three much larger thin, white, obovate petals with yellow bases. Rudiments of an androecium are present in two forms: three or four short, yellow, laterally connate staminodia which might function in insect attraction occur opposite each petal (Figures 7, 9, and 18), and longer awl-shaped, hairy, yellow staminodia which are only occasionally basally connate occur in groups of three or four opposite the sepals (Figures 7, 9, and 18). Each of the 12-20 or so carpels bears two long bright yellow stigmatic arms $1 / 3^{-1 / 2}$ the length of the petals (Figures 7 and 18). The stigmatic arms are hairy on their inner faces and these hairs grade into similar transmitting tissue in the stylar region (Figure 18).

Within the rather large inferior ovary the carpels are only slightly fused (Figure 19). The large vascular bundle near the juncture of adjacent carpels supplies parts of the network of tiny placental bundles to the adjacent carpels and is an indication that the carpels are fused to each other as well as to the floral cup. The line of fusion of the carpels to the floral cup cannot be distinguished at any time. The carpels are completely connate only briefly at their extreme bases where they 

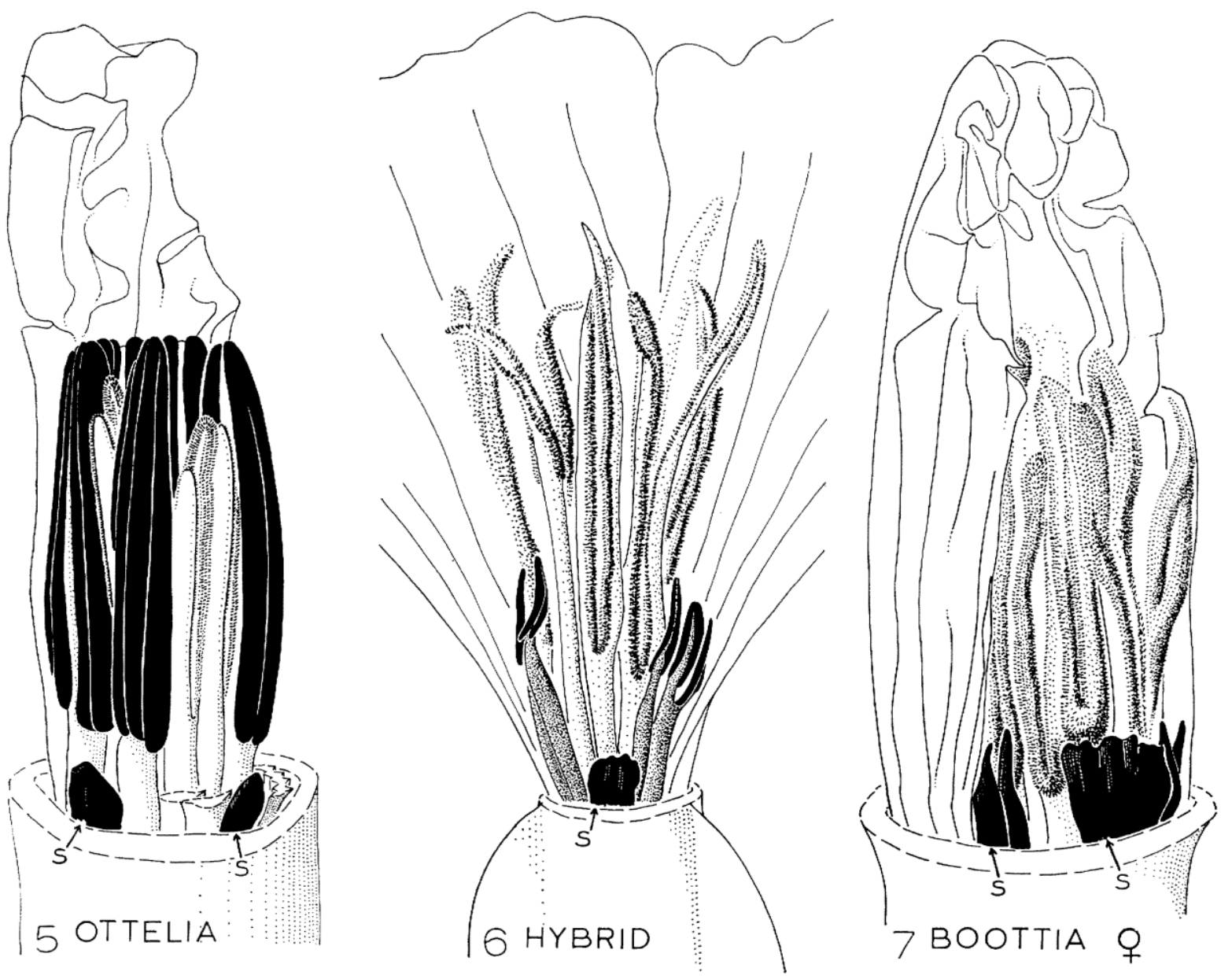

Figure 5. Ottelia alismoides. Upper portion of flower near anthesis with perianth cut away except for one un- expanded petal. Two stamens removed to reveal unequal stigmatic arms. X 5. | Figure 6. The hybrid in anthesis. Stigmatic arms are spread and some fertile and partially fertile stamens and one group of fused staminodia are shown X 5. | Figure 7. Boottia cordata, female, partially dissected upper portion of flower just before anthesis. Stigmatic arms still appressed. Awl-shaped staminodia and one group of fused staminodia shown. X 5.

join the receptacle. The laminae of the carpels are broad and extend nearly to the center of the ovary (Figures 18 and 19). The carpels are completely open for their entire length and their ventral margins are rarely even conduplicately appressed. Placentation is laminar and numerous multicellular mucilage glands occur among the ovules (Figure 19).

The flower is open for only 1 day, following which the peduncle bends and pulls the flower and its enveloping spathe under water. The corolla disintegrates almost immediately but the calyx persists until the fruit is ripe. Seeds mature under water and they are liberated when the fruit disintegrates. They may germinate immediately, but they retain their viability for at least 5 years when dried.

The spathe primordium arises as a ring around the inflorescence apex, and the entire apex above this ring then becomes the single flower primordium. As the spathe elongates as a tube the flower primordium also elongates and soon becomes very flat-topped. This flatness is a result of elongation of the margins of the floral apex relative to the elongation of its tip, but growth of the tip does not cease until the organ primordia are visible. Two sets of primordia can be distinguished at this time: the sepals, and the common primordia of the petals, androecium, and gynoecium. The petals arise consecutively and with the other organ primordia.

The staminodial primordia are at first globose (Figures 15 and 16). Some of them elongate and become awlshaped staminodia while those opposite the petals remain rounded and become fused. The awl-shaped staminodia arise more or less simultaneously, but those which appear in the corners of the floral apex may be slightly delayed. The antipetalous staminodia seem to arise slightly below the awl-shaped staminodia. The petals arise simultaneously with the staminodia but they 

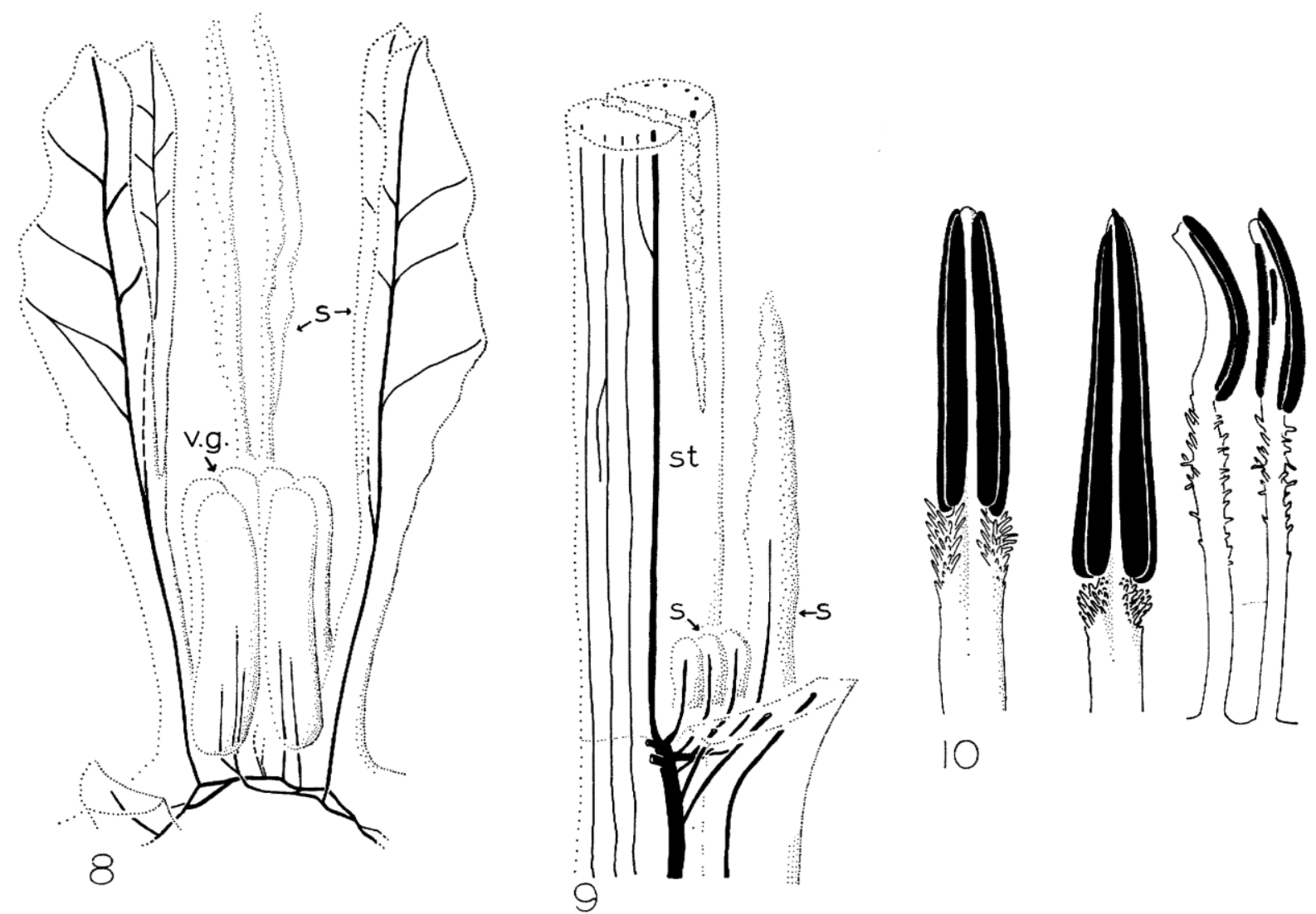

Figure 8. Boottia cordata, inner structures of male flower in anthesis. The three bifid staminodia surround the vestigial gynoecium. Vascular supply shown departing from the receptacular plexus. X 5. | Figure 9. Boottia cordata. Vascular supply to the awl-shaped staminodium, a group of fused staminodia, and one style shown for female flower. X 4 . I Figure 10. Stamens, 1. to r., of Boottia cordata, Ottelia alismoides, and their hybrid. X 4.-s, staminodia; st, style; v.g., vestigial gynoecium.

remain arrested in their growth until anthesis. Each staminodium is independently sup- plied with a single bundle from the stylar plexus of vascular tissue (Figure 9).

It is possible to distinguish individual carpel primordia very early. Not all of the carpels and their associated staminodia arise simultaneously. Rather, those which arise in the two or three sharp angles of the floral apex formed by the enveloping spathe appear slightly after the others (Figure 15), but these groups become indistinguishable by the stage shown in Figure 16. Each carpel appears at first as two projecting laminae (Figure 15). As the lengthening continues the upper parts of these laminae elongate while the lower parts broaden (Figures 16 and 17). The upper parts become the stylar arms and their final elongation occurs rapidly at anthesis. The flat residual floral apex persists to maturity (Figure 18), although it is greatly overwhelmed by the carpels. Vascular patterns in the gynoecium are illustrated elsewhere (Kaul, 1968a).

\section{Bisexual flower of Ottelia alismoides}

Ottelia alismoides is a submerged monoclinous aquatic native in shallow fresh water of the tropics and subtropics from Africa to Japan. Ordiniarily only the perianth and stigmas extend above the water (Figure 4). One sessile flower is produced in each inflorescence and it is ensheathed by a spathe of fused and fluted bracts (Figure 4). The flower is similar in aspect to that of the female Boottia cordata but it is about half as large and considerably less showy. Nine or so stamens occur in a single whorl opposite the sepals. These stamens are occasionally laterally connate at their bases. Groups of fused staminodia somewhat similar to those seen in female Boottia cordata occur opposite the petals (Figure 5). Vascularization of the androecium is also similar in that each fertile stamen is vascularized independently from the stylar plexus, and an independently arising bundle serves each staminodium. 

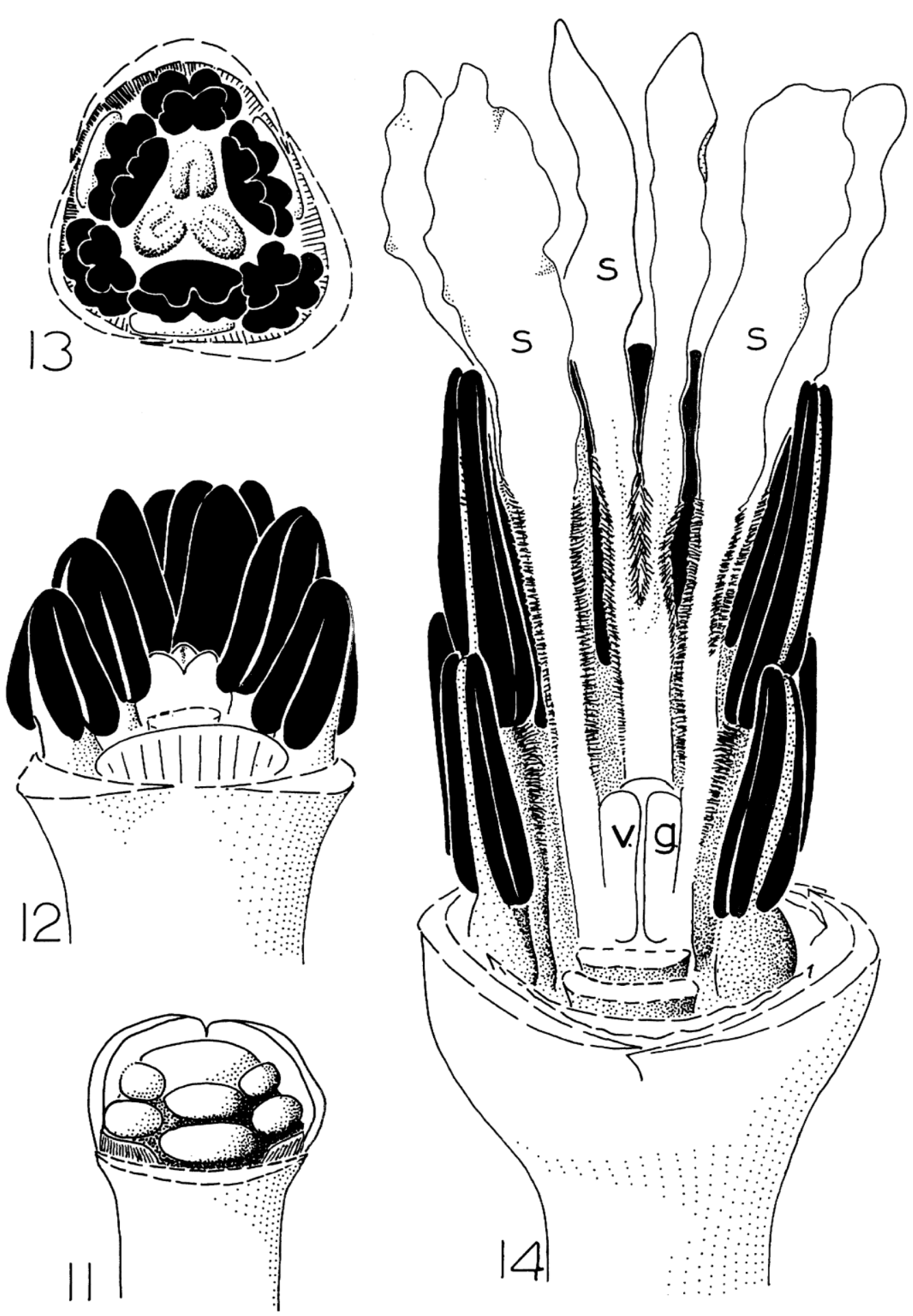

Figures 11-14. Development of male flower of Boottia cordata. | Figure 11. Perianth and fertile stamen primordia have appeared. One sepal removed. X 9. | Figure 12. Later stage showing primordia of vestigial gynoecium. Calyx and two stamens removed. X 12. | Figure 13. Polar view at same stage as Figure 12 showing crescent-shaped free primordia of vestigial gynoecium. X 11. | Figure 14. Flower at anthesis with perianth and two stamens removed. The staminodia are adnate to the fused carpels of the vestigial gynoecium. X 7.5. - s, staminodia; v.g., vestigial gynoecium. 
The stamens have rather short, broad, distally hairy filaments and relatively broad connectives (Figures 5, 10). The stamens arise first and the staminodia appear soon thereafter and slightly below, although their vascular bundles actually depart slightly above those to the stamens.

The six to nine or more carpels each have two long unequal stigmatic arms whose inner faces are hairy to their bases, where the hairs merge into the transmitting tissue (Figure 5). As in Boottia cordata the carpels are open for their entire length and their ventral margins are barely conduplicately appressed if at all (Figure 20). Common vascular bundles near the juncture of the abaxial carpel walls with the floral cup provide some of the small placental bundles to placentae of adjacent carpels. Placentation is laminar, but there are no ovules at the extreme margins of the carpels or near the dorsal bundle (Figure 20). Mucilage glands are abundant on the laminae (Figure 20).

Ontogeny is similar to that of Boottia cordata, but with fewer carpels there is no noticeable lag in appearance of those carpels which develop opposite the corners of the spathe. Carpel fusion is congenital, appearance of the stamens is simultaneous and is followed by the nectaries, the whorls of organs appear in acropetal sequence, and there is a residual floral apex. Fruits mature under water and the seeds are liberated when the fruit disintegrates in the persistent spathe.

\section{The hybrid}

The hybrid of the dioecious Boottia cordata with the monoclinous Ottelia alismoides shows features of both parents. All 31 hybrid plants grown showed great similarities in their flowers and all produced only-perfect flowers. In general vigor the hybrid resembles Boottia and the flowers are showy and held above the water as they are in Boottia (Figure 3). The leaves are intermediate in character, being more delicate than those of Boottia but more leathery than those of Ottelia. They are submerged or partially floating, but never completely floating. In general outline they are intermediate too (Figure 3). The spathe is also intermediate in that it is less fluted than Ottelia's and less warty than Boottia's.

The androecium consists of antipetalous fused staminodia and partially fertile antisepalous stamens (Figures 6 and 10). Some of the stamens are laterally connate for various distances; most of them are imperfectly developed but they produce small quantities of viable pollen. Each stamen receives a single vascular bundle which does not branch and each staminodium receives a single bundle from the stylar plexus.

The six to nine carpels have long stigmatic arms similar to those of the parents (Figure 6). The carpels are like those of Boottia in that they are laterally connate only for a very short distance from the floral cup, but in their numbers they resemble Ottelia (Figure 20).

\section{Discussion}

There is little doubt that these taxa exhibit some of the most primitive floral morphology in the family, and despite the inferior ovary and dioecious habit, they are relatively primitive among the monocotyledons. The numerous open carpels with laminar placentation, the residual floral apex, and the minimal fusions except those associated with the inferior ovary are primitive features. The phylogeny of these and other characters of the family are considered elsewhere (Kaul, 1968a).

The androecium shows some specializations, particularly in its meristic stabilization and in its staminodial modifications. The evidence presented here from the hybrids and from vascular anatomy supports the view that the vestigial structures in the flowers of $O t$ telia and female Boottia are sterilized stamens. The staminodial nature of the three bifid structures of the male Boottia flower is supported by their vasculature which, as in the fertile stamens, is a single bundle, and by their location as a fifth androecial whorl alternate with the fourth fertile whorl. The function of these elaborate staminodia might be revealed by field studies of pollination mechanisms.

The nature and rationale of the inferior ovary have been considered by Douglas (1944, 1957), Puri (1952), Eames (1961), Boke (1964), Kaplan (1967), and others and need no elaboration here. As far as is known the inferior ovary in all monocotyledons is appendicular, and in the Hydrocharitaceae the appendicular structure is quite obvious. In Ottelia and Boottia adnation of the carpels to the floral cup is so complete that the carpellary bundles and most of the bundles of the appendages have become fused. Various stages of the phylogenetic congress of these bundles are seen in other genera of the family (Kaul, 1968a).

The three crescent-shaped primordia at the center of the male Boottia flower support the view that there is a vestigial superior gynoecium. Further, more than one bundle is associated with each of these primordia (Figure 8). Ontogenetic fusion of the three vestigial carpels and their modified structure at maturity obscure their gynoecial nature at anthesis. Of interest and phylogenetic significance here is the fact that this rudimentary gynoecium is superior in a family noted for its functional inferior ovary. Similar structures, presumably gynoecial too, occur in other genera of the family. The vestigial superior gynoecium suggests that the dioecious condition preceded the evolution of the inferior ovary in the Hydrocharitaceae.

There is no evidence here or anywhere else in the family that the carpels have ever been anything but completely open. Further, there is no evidence in the Butomaceae, the family closest to the Hydrocharitaceae, that significant carpel closure has ever occurred in these primitive monocotyledons (Kaul, 1967, 1968b). 


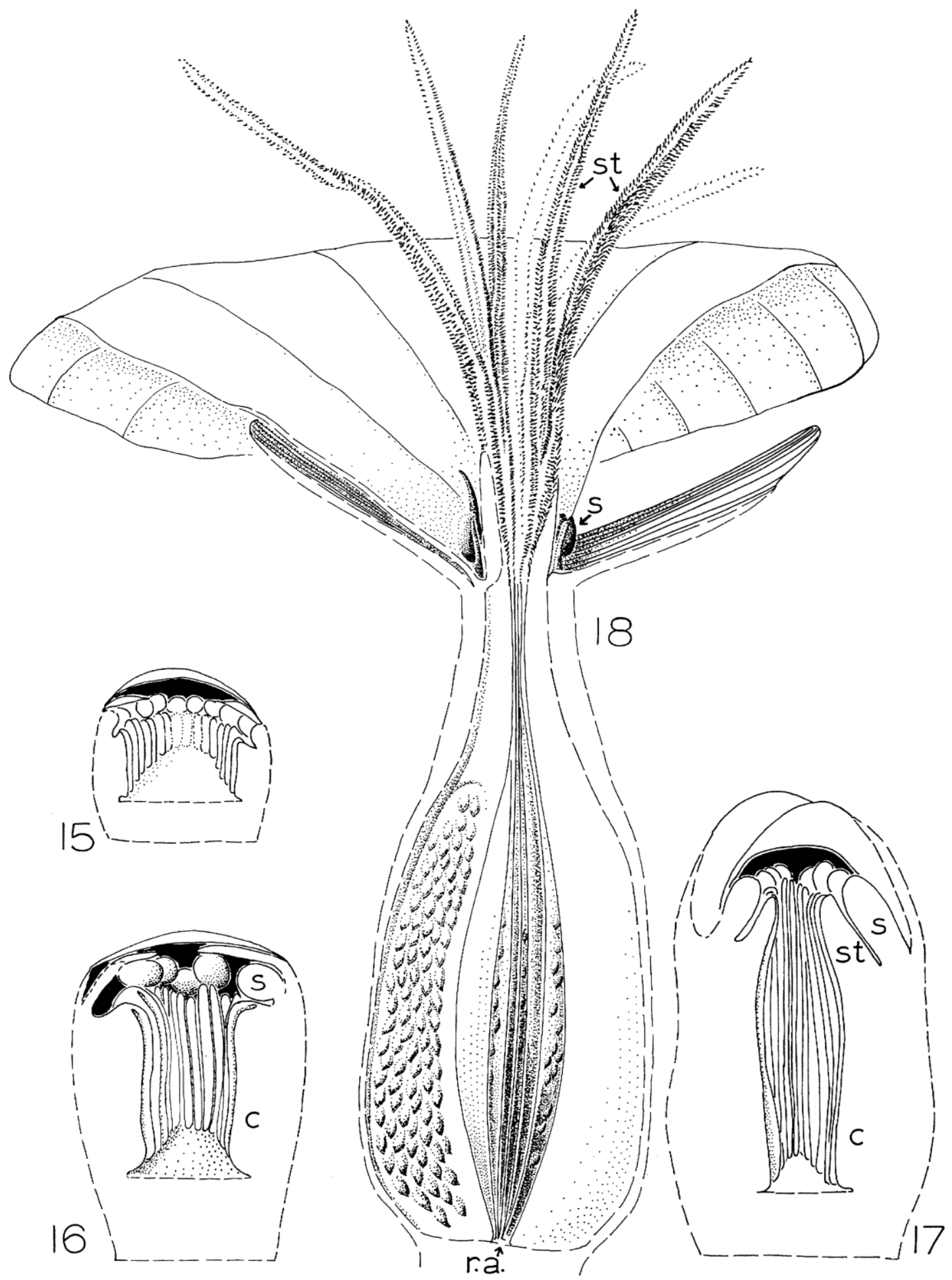

Figures 15-18. Development of female flower of Boottia cordata. | Figure 15. Longitudinally halved primordium shortly after carpel, staminodium, and petal primordia have differentiated. Corner primordia somewhat delayed in development. X 25. | Figure 16. Older stage preceding elongation of stylar region. X 50. | Figure 17. Older stage as stylar region is elongating. Ovule primordia appear at this time. X 45. | Figure 18. Longitudinally halved flower at anthesis. Vestigial androecium has matured. Carpels are open for their entire length and a residuial apex is present. X 4.5. $-c$, carpel; r.a., residual apex; s, staminodium; st, style and stigma. 


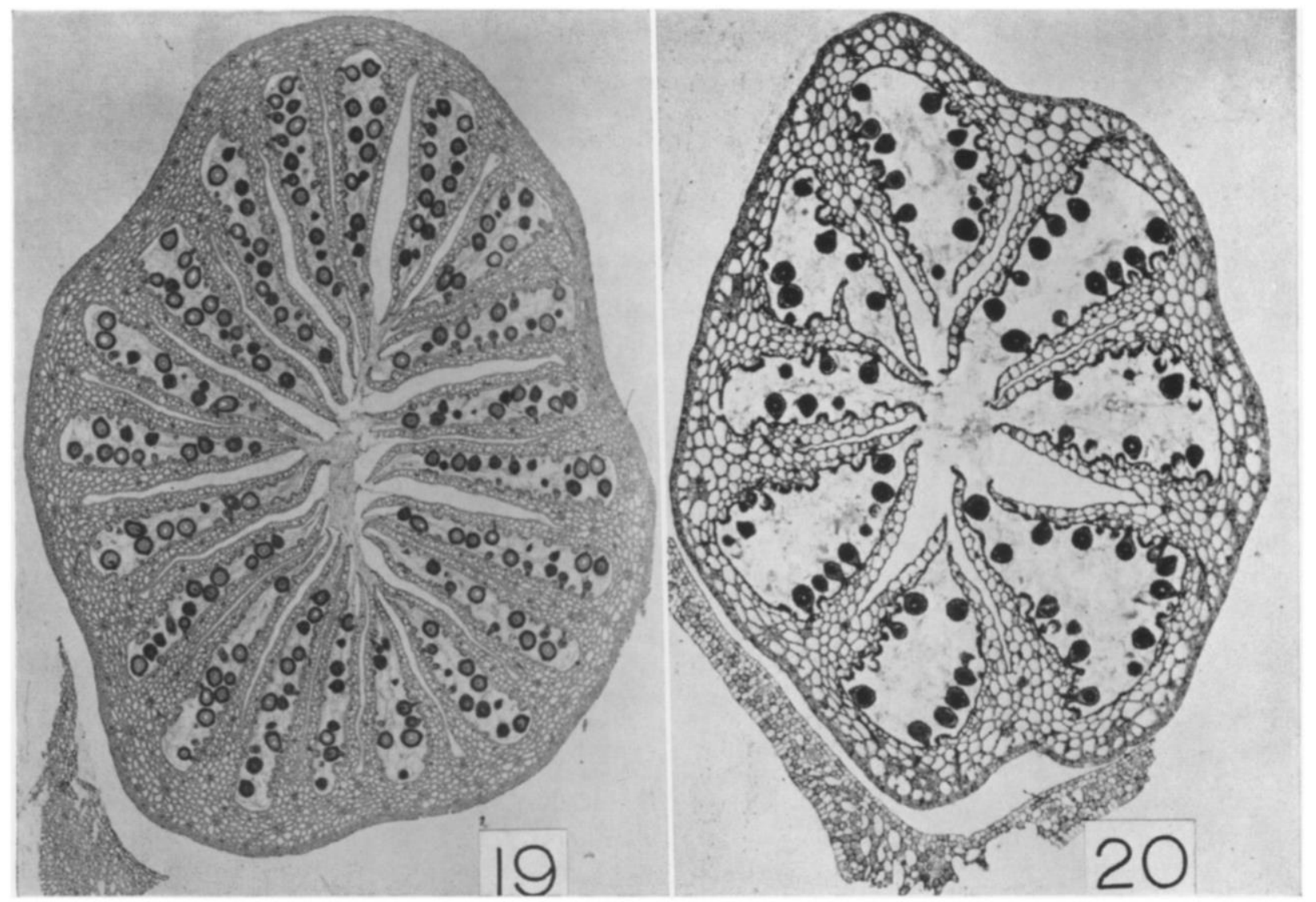

Figures 19 and 20. Cross sections of ovaries at anthesis. | Figure 19. Boottia cordata with 20 carpels. Some adjacent carpels are more completely fused than others. The numerous mucilage glands among the ovules fill the locules with mucilage. X 6. | Figure 20. Ottelia alismoides with 8 carpels. Gray material in locules is mucilage. X 15.

Although the gynoecium in the family some- times has been considered to be apocarpous, clear evidence of carpel fusion is seen in the sharing of vascular bundles by adjacent carpels in Ottelia and Boottia. It is likely that the development of partial syncarpy was a concomitant of the fusion of the appendage bases to the carpels as the appendicular inferior ovary evolved. Carpel fusion is clearly congenital, as is fusion of the carpels to the floral cup. Taken as a whole and in the context of related families, the Hydrocharitaceae shows evidence that its inferior ovary arose independently of other monocotyledonous inferior ovaries, perhaps as an adaptation to the derived submerged habit.

The Hydrocharitaceae appears to be somewhat remote from other families of monocotyledons except the Butomaceae and Alismaceae. Except for the inferior ovary, similarities of the gynoecia of Ottelia and Boottia to that of the butomaceous Limnocharis flava are great (cf. Kaul, 1967). All have numerous essentially open carpels of similar configuration and laminar placentation. However, the much-elongated stigmatic arms of
Ottelia and Boottia contrast with the primitive stigmatic crest of Limnocharis and the poorly defined style and stigma of Hydrocleis (Kaul, 1968b) and Butomus. Carpel fusion in the Butomaceae and Alismaceae is as nominal as it is in the Hydrocharitaceae. In all these families it is associated with fusion of the carpels to noncarpellary tissue-the receptacle in the Butomaceae and Alismaceae, and the floral cup in the Hydrocharitaceae. The centrifugally developed androecium of Limnocharis and Hydrocleis has no known counterpart in the Hydrocharitaceae.

Clearly the Butomaceae is more primitive in its floral morphology than the Hydrocharitaceae. It is likely that both families, and the Alismaceae, have had a common ancestry from stock resembling the Butomaceae. The assumption of the submerged habit and the evolution of hydrophilous pollination are paralleled in the Hydrocharitaceae by morphological adaptations such as the inferior ovary and reduced floral structures. Relatively early stages in this reduction are seen in Ottelia and Boottia. The Butomaceae and Alismaceae are mostly 
entomophilous emergent marsh plants and as such lack the extreme floral reduction of some Hydrocharitaceae. Field studies of pollination in these families are needed to pro- vide correlations of floral morphology with pollination mechanisms. Hartog (1957) and Sculthorpe (1967) have summarized the meager knowledge of pollination in the family.

Interesting comparisons of the dicotyledonous Nymphaeaceae, sensu lato, with the Hydrocharitaceae may be made. Nymphaea shows tendencies toward syncarpy and an inferior ovary (Moseley, 1961), and Nymphaea, Nuphar, Victoria, Euryale, and Barclaya have numerous carpels and laminar placentation and exhibit a rather complete series from hypogyny to epigyny. Cabomba and Brasenia are trimerous and exhibit reduced placentation very like that of some of the more specialized Hydrocharitaceae. These may be parallel developments of the two families in similar habitats, but the intriguing possibility that the two families may be related via the Butomaceae should not be overlooked. Hints of such a bridge from the monocotyledons to the dicotyledons are provided in the large number of vegetative and floral characteristics shared by these families.

\section{Literature Cited}

Boke, N. H. 1964. The cactus gynoecium: a new interpretation. American Journal of Botany 51: 598-610.
Douglas, G. E. 1944. The inferior ovary. Botanical Review 10: 125-186.

Douglas, G. E. 1957. The inferior ovary. II. Botanical Review 23: 1-46.

Eames, A. J. 1961. Morphology of the angiosperms. McGraw-Hill, New York.

Ernsy-Schwarzenbach, M. 1956. Kleistogamie und Antherenbau in der Hydrocharitaceen-Gattung Ottelia. Phytomorphology 6: 296-311.

Hartog, C. den. 1957. Hydrocharitaceae, p. 381-413. In C. G. G. J. van Steenis [editor], Flora Malesiana 5(1). P. Noordhoff.

Kaplan, D. R. 1967. Floral morphology, organogenesis and interpretation of the inferior ovary in Downingia bacigalupii. American Journal of Botany 54: 1,274-1,290.

Kaul, R. B. 1967. Ontogeny and anatomy of the flower of Limnocharis flava (Butomaceae). American Journal of Botany 54: 1,223-1,230.

Kaul, R. B. 1968a. Floral morphology and phylogeny in the Hydrocharitaceae. Phytomorphology 18: 13-35.

Kaul, R. B. 1968b. Floral development and vasculature in Hydrocleis nymphoides (Butomaceae). American Journal of Botany 55: 236-242.

Moseley, M. F. 1961. Morphological studies of the Nymphaeaceae II. The flower of Nymphaea. Botanical Gazette 122: 233-259.

Puri, V. 1952. Floral anatomy and the inferior ovary. Phytomorphology 2: 122-129.

Sculthorpe, C. D. 1967. The biology of aquatic vascular plants. St. Martin's Press, New York. 